\title{
Digitalisering ad modum Statens legemiddelverk
}

Etter ti år med omhyggelige studier publiserte den engelske legen William Withering i 1785 monografien On the foxglove and some of its medical uses, with practical remarks on the dropsy, and some other diseases. Siden er behandling med ekstrakter fra revebjelle (Digitalis purpurea) og etter hvert renfremstilte digitalispreparater blitt brukt ved hjertesvikt og supraventrikulære takyarytmier. Det mer enn 230 år gamle terapiprinsippet er omdiskutert: En placebokontrollert studie fra «the digitalis investigation group» (DIG) som omfattet nær 7000 pasienter med hjertesvikt, viste at digitalisterapi reduserer symptomtrykk, men ikke dødelighet (1).

Digitalispreparater kan være svært giftige. Da 0,25 mg digoksintabletter ble substituert med feilproduserte tabletter som inneholdt 0,20 $\mathrm{mg}$ digitoksin og $0,05 \mathrm{mg}$ digoksin (noe som tilsvarer omtrent en tredobling av dosen) i og rundt byen Veenendaal i Nederland i 1969, utviklet nesten alle de eksponerte pasientene alvorlige og potensielt livstruende forgiftninger (2). I en lederartikkel til DIG-studien påpekte den amerikanske kardiologen Milton Packer misforholdet mellom ytelse og risiko, og skrev at «digoxin's inability to substantially influence morbidity and mortality eliminates any ethical mandate for its use and effectively relegates it to be prescribed for the treatment of persistent symptoms after the administration of drugs that reduce the risk of death and hospitalization (such as angiotensinconverting-enzyme inhibitors and beta-adrenergic blockers)» (3).

I dette nummer av Tidsskriftet rapporterer Christian Haga og medarbeidere om feil og problemer som oppsto da det før avregistreringen av digitoksin i 2011 utgikk bud fra Statens legemiddelverk om at mer enn 20000 norske pasienter skulle bytte til digoksin (4). Data fra Giftinformasjonen, RELIS og Oslo universitetssykehus viser at byttet avstedkom både overdoseringer og dødsfall. Haga og kolleger skal ha takk for å ettergå og fortelle denne nå snart fem år gamle historien. Forfatterne har akslet store og trolig også frustrerende utfordringer: Spontanrapporteringssystemene (Giftinformasjonen og RELIS) vil, som forfatterne også selv påpeker (4), underestimere problemene. Retrospektive gjennomganger av serumkonsentrasjonsdata er åpne for feiltolkninger, og studiens datagrunnlag burde kanskje også inkludert flere sentra enn Oslo universitetssykehus. Og forfatternes konklusjon - «selv med et godt informasjonsarbeid fra legemiddelmyndighetene så man en liten og forbigående økning i antall overdoseringer og rapporterte dødsfall» (4) bør ikke bli siste ord.

Haga og medarbeidere omtaler flere av ankepunktene: Legemiddelverkets veileder Overgang fra digitoksin til digoksin hos voksne (5) ble endret underveis i bytteprosessen med reduksjoner av veiledende døgndoser og uten at endringene ble tydeliggjort. På grunn av leveringsproblemer tillot Legemiddelverket markedsføring av digoksinpreparater med forskjellige styrkeangivelser (4), noe som kan øke risikoen for feildoseringer. Legemiddelmyndighetene sikret ikke tilstrekkelige beredskapslagre av inaktiverende digoksinantistoffer (4), som har en sentral plass i behandlingen av alvorlige forgiftninger. Mangel på nødvendige preparater, endring av doseringsanbefa- linger underveis og uensartet merking av legemidlene hører ikke hjemme i en bytteprosess. I veilederen (5) poengterte man dessuten at «Pasienter som bruker digitoksin $m a ̊$ (vår uthevelse) derfor gå over til digoksin», og først i tredje utgave av Nytt om legemidler viet byttet, publisert langt ut $\mathrm{i}$ bytteprosessen våren 2012, nevnes det at man også burde overveie «om pasienten fortsatt trenger et digitalispreparat» (6). Den insisterende anmodningen om bytte står i kontrast til Milton Packers allerede siterte begrunnelse (3) for at man i stedet for å fokusere på byttet burde grepet muligheten til å undersøke hvilke pasienter som kunne leve godt uten digitalis. Og siden prosessen involverte giftige legemidler til gamle og sårbare pasienter, kunne sentrale legemiddelmyndigheter monitorert, eller i det minste tatt initiativet til å monitorere, konsekvensene av byttet. For eksempel ville innhenting av personidentifiserende opplysninger gjort det mulig å følge opp hendelsene på en annen måte enn hva Giftinformasjonen og RELIS rutinemessig gjør. På samme måte kunne sykehusene registrert alle innleggelser som skyldtes overdoseringer med digitalis. Dette ville produsert kvalitetskontrollerte nasjonale data om resultatene, gitt oss alle viktige erfaringer med hvordan store omlegginger i legemiddelbruk best organiseres, og spart Haga og medarbeidere for arbeidet med å rydde opp post festum.

I stedet ser vi tilbake på et bytte som både ble unødig farlig og dårlig dokumentert. Veien til Veenendaal er kort ...

\section{Lars Slørdal \\ lars.slordal@ntnu.no \\ Anne Elise Eggen}

Lars Slørdal (f. 1955) er professor ved Norges teknisk-naturvitenskapelige universitet og overlege ved Avdeling for klinisk farmakologi, St. Olavs hospital.

Forfatter har fylt ut ICMJE-skjemaet og oppgir ingen interessekonflikter.

Anne Elise Eggen (f. 1958) er professor ved Institutt for samfunnsmedisin, Universitetet i Troms $\varnothing$ - Norges arktiske universitet.

Forfatter har fylt ut ICMJE-skjemaet og oppgir ingen interessekonflikter.

Litteratur

1. Digitalis Investigation Group. The effect of digoxin on mortality and morbidity in patients with heart failure. N Engl J Med 1997: 336: 525-33

2. Lely $\mathrm{AH}$, van Enter CHJ. Large-scale digitoxin intoxication. BMJ 1970; 3: 737-40.

3. Packer $\mathrm{M}$. End of the oldest controversy in medicine. Are we ready to conclude the debate on digitalis? N Engl J Med 1997; 336: 575-6.

4. Haga C, Opdal M, Tuv S et al. Legemiddelsikkerhet ved bytte av digitalispreparat i Norge. Tidsskr Nor Legeforen 2016; 136: 1714-8.

5. Statens legemiddelverk. Overgang fra digitoksin til digoksin hos voksne. http://legemiddelverket.no/Nyheter/Bivirkninger/Sider/ Overgang-fra-digitoksin-til-digoksin-hos-voksne.aspx (1.9.2016).

6. Statens legemiddelverk. Nytt om legemidler. Overgang fra digitoksin til digoksin hos voksne. http://legemiddelverket.no/Nyheter/NYL/Sider/

Nytt-om-legemidler-nr-6,-27.-mars-2012.aspx (1.9.2016). 